\title{
PENGARUH RASIO KEUANGAN DAN MAKROEKONOMI TERHADAP FINANCIAL DISTRESS PADA PERUSAHAAN SEKTOR INDUSTRI BARANG KONSUMSI YANG TERDAFTAR DI BEI PERIODE 2015-2019
}

\author{
Vynda Myllariza \\ Universitas Negeri Surabaya \\ vynda.17080574114@mhs.unesa.ac.id
}

\begin{abstract}
Financial distress is a condition that occurs in a company that is characterized by financial difficulties, and if it occurs continuously, it will cause bankruptcy, so analysis is needed to determine the factors that influence these conditions. This study aimed to determine the factors that affect the company's financial distress in the consumer goods industry sector. Predictors used as independent variables are financial ratios which include return on assets, return on equity, current ratio, debt to assets ratio, debt to equity ratio, and macroeconomics (inflation and exchange rates) to predict financial distress in companies. The type of research used is causal associative. In taking the research sample using purposive sampling technique and obtaining 26 companies in the consumer goods industry sector listed on the Indonesia Stock Exchange for the 2015-2019 period. Data analysis techniques in the form of logistic regression with SPSS. The results of this study indicate that the financial ratio variables used do not affect financial distress. In addition, macroeconomic variables, which include inflation and exchange rates, also have no significant effect on financial distress.
\end{abstract}

Keywords: exchange rates; financial distress; financial ratio; inflation.

\section{PENDAHULUAN}

Tahun 1998 dan 2008 krisis keuangan melanda dunia secara global yang menyebabkan banyak perusahaan mengalami kondisi kesulitan keuangan sehingga perusahaan mengalami kebangkrutan (Simanjuntak et al., 2017). Kondisi kesulitan keuangan ini ditandai dengan penurunan profitabilitas dan arus kas yang terjadi secara terus-menerus pada obligasi perusahaan. Ketika perusahaan tidak mampu menghadapi dan mengatasi perubahan keuangan yang terjadi secara tidak terduga, maka menyebabkan perusahaan tersebut mengalami financial distress. Kegagalan perusahaan dalam mengantisipasi suatu masalah pada keuangan perusahaan merupakan faktor penyebab utama terjadinya financial distress (Thim et al., 2011).

Financial distress yaitu kondisi yang dialami perusahaan disebabkan oleh kondisi keuangan yang tidak sehat sebelum pada akhirnya mengalami kebangkrutan (Platt \& Platt, 2002). Kebangkrutan merupakan kondisi yang tidak ingin dialami seluruh perusahaan, oleh karena itu perusahaan harus memiliki cara untuk mengantisipasi setiap aspek atau faktor yang akan berdampak buruk pada perusahaan. Untuk meminimalisir risiko perusahaan mengalami financial distress, perusahaan dapat melihat dan memprediksi sejak dini kondisi keuangan perusahaan, sehingga perusahaan mampu menyusun dengan tepat cara atau langkah yang akan dilakukan dan meminimalisir terjadinya kondisi financial distress (Widhiari \& Aryani Merkusiwati, 2015).

Penelitian ini menggunakan profitabilitas nilai Earning Per Share (EPS) sebagai indikator kondisi financial distress pada perusahaan. Menurut Tandelilin (2010) EPS ialah rasio keuangan guna mengukur keuntungan bersih yang didapatkan setiap lembar sahamnya. Nilai EPS mempresentasikan total laba atau keuntungan perusahaan yang akan diterima oleh shareholders setiap tahunnya. Tingginya nilai EPS pada suatu perusahaan mengindikasikan keberhasilan perusahaan dalam mengelola keuangan sehingga mampu mendapatkan keuntungan yang tinggi. Sebaliknya, apabila nilai EPS rendah mengindikasikan keuntungan yang didapat oleh shareholders juga rendah karena perusahaan mengalami penurunan kinerja. Apabila perusahaan mengalami kondisi penurunan kinerja secara kontinyu maka dapat berdampak negatif bagi perusahaan, karena dapat meningkatkan probabilitas perusahaan mengalami financial distress (Sari \& Hartono, 2020). Data EPS tiap sektor perusahaan yang tercatatdi BEI periode 2015-2019 ditunjukkan dalam gambar 1. 
Vynda Myllariza. Pengaruh Rasio Keuangan dan Makroekonomi terhadap Financial Distress Perusahaan Sektor Industri Barang Konsumsi yang Terdaftar di BEI Periode 2015-2019

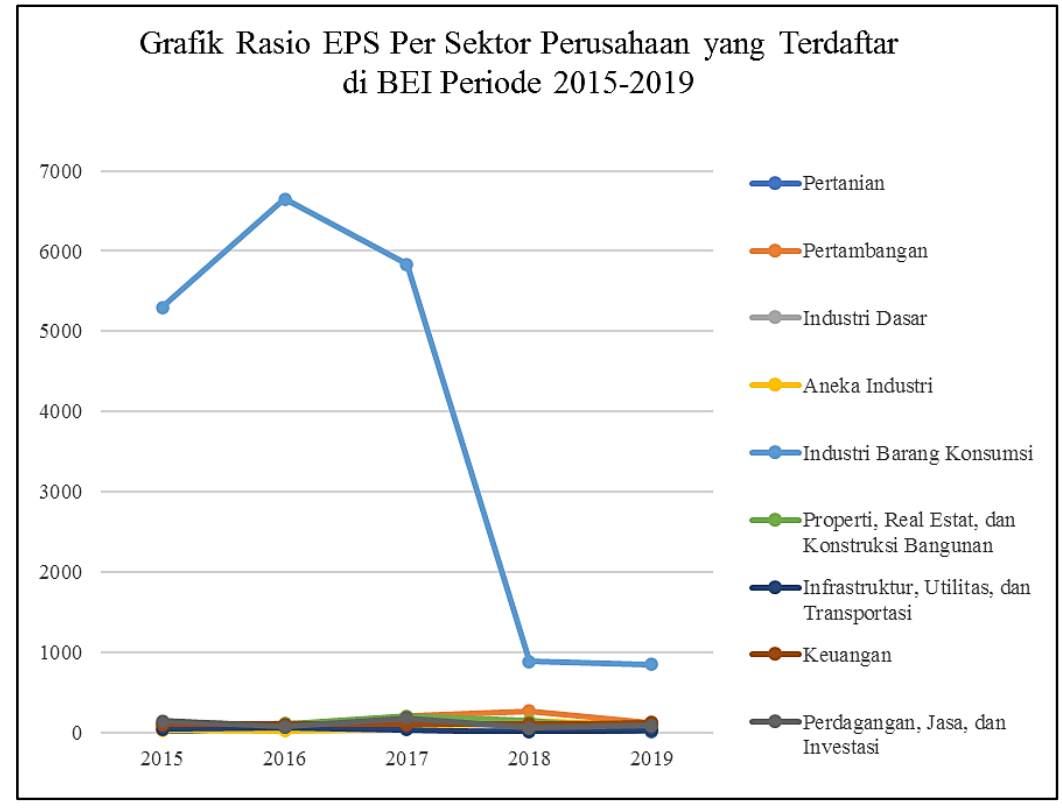

Sumber: idx.co.id (2021, data diolah)

\section{Gambar 1. RASIO EPS PER SEKTOR PERUSAHAAN YANG TERDAFTAR DI BEI PERIODE 2015-2019}

Gambar 1 menunjukkan pergerakan rata-rata EPS 9 sektor perusahaan yang tercatat di BEI dari tahun 2015-2019 bergerak secara fluktuatif. Sektor industri barang konsumsi termasuk sektor yang menunjukkan grafik nilai EPS paling fluktuatif yang dapat dilihat pada 2017-2019 mengalami penurunan yang cukup signifikan dibandingkan dengan sektor lainnya. Oleh karena itu, penelitian ini memilih sektor industri barang konsumsi sebab fenomena tersebut menarik untuk dijadikan obyek penelitian.

Financial distress yang dialami perusahaan dapat dikarenakan beragam sebab, diantaranya internal serta eksternal perusahaan (Priyatnasari \& Hartono, 2019). Menurut Erayanti (2019) aspek internal dapat menggunakan rasio keuangan perusahaan yang meliputi rasio profitabilitas diproksikan oleh Return on Asset (ROA) dan Return on Equity (ROE), rasio likuiditas diproksikan oleh Current Ratio (CR), serta rasio leverage yang diproksikan oleh Debt to Asset Ratio (DAR), serta Debt to Equity Ratio (DER). Sedangkan untuk aspek eksternal dapat menggunakan indikator makroekonomi yang dapat diproksikan oleh inflasi dan nilai tukar (Darmawan, 2017).

Financial distress memanfaatkan rasio profitabilitas dapat ditentukan melalui perbandingan ROA serta ROE. ROA mengukur efektifitas dan efisiensi perusahaan dalam mengelola seluruh asetnya. Nilai ROA yang tinggi menandakan bahwa perusahaan mampu mengelola seluruh aset dan sumber daya yang dimiliki sehingga tingkat keuntungan yang dihasilkan juga tinggi, dan sebaliknya (Sucipto \& Muazaroh, 2017). ROE yang besar mengindikasikan perusahaan sanggup mengelola modal yang dipunyai guna mendapatkan keuntungan (Fatmawati \& Rihardjo, 2017; Maulida et al., 2018). Marfungatun (2016), Murni (2018), Rohmadini et al. (2018) menyatakan ROA dan ROE tidak memengaruhi financial distress.

Pengukuran financial distress menggunakan rasio likuiditas dinilai melalui rasio CR (Erayanti, 2019). Aisyah et al. (2017) menyatakan bahwa CR yang tinggi mengindikasikan kesanggupan perusahaan untuk membiayai seluruh utang jangka pendeknya, namun apabila nilai CR rendah maka kesanggupan perusahaan guna membiayai kewajiban jangka pendeknya juga rendah karena tingginya kewajiban yang dimiliki oleh perusahaan. Apabila kondisi tersebut terjadi secara berkelanjutan, dapat menimbulkan kerugian bagi perusahaan yang akan mengakibatkan pada kondisi financial distress. Hasil penelitian dari Budiarso (2014), Yustika (2015), dan Ginting (2017) menunjukkan CR berdampak ke financial distress. Sebaliknya penelitian Marfungatun (2016), Pertiwi (2018) dan Priyatnasari \& Hartono (2019) menunjukkan tidak adanya pengaruh antara CR pada financial distress. 
Penentuan financial distress dengan rasio leverage pengukurannya melalui perbandingan DAR dan DER. DAR berfungsi guna mengukur besaran utang perusahaan untuk membiayai asetnya. Tingginya nilai DAR pada suatu perusahaan menunjukkan tingginya hutang yang dimiliki. Hutang yang tinggi pada perusahaan akan menyebabkan gagal bayar yang akan memicu terjadinya financial distress (Andre \& Taqwa, 2014). Tingginya nilai DER menunjukkan besar komposisi hutang dibanding ekuitas perusahaan yang berarti bahwa dalam membiayai seluruh kegiatannya perusahaan menggunakan hutang yang lebih besar daripada modalnya sendiri. Besarnya hutang yang dimiliki oleh perusahaan dapat meningkatkan risiko kesulitan keuangan (Wahyuni et al., 2020). Namun hasil penelitian dari Setiawan et al. (2017), Murni (2018), dan Pertiwi (2018) menunjukkan DAR dan DER tidak memengaruhi financial distress.

Financial distress dengan menggunakan makroekonomi diproksikan dengan inflasi dan nilai tukar. Tingkat inflasi tinggi disebabkan adanya kenaikan pada harga barang. Permintaan masyarakat terhadap suatu barang akan menurun seiring dengan kenaikan harga yang terjadi. Hal tersebut juga akan berdampak pada kegiatan produksi yang menyebabkan penjualan pada perusahaan akan menurun yang diakibatkan oleh berkurangnya permintaan (Darmawan, 2017). Melemahnya nilai tukar akan berdampak pada depresiasi rupiah yang menyebabkan kenaikan biaya produksi. Hal tersebut akan meningkatkan probabilitas perusahaan mengalami kondisi financial distress karena adanya penurunan profitabilitas pada perusahaan (Darminto, 2010). Namun hasil penelitian dari Darmawan (2017) dan Priyatnasari \& Hartono (2019) menunjukkan inflasi dan nilai tukar tidak memengaruhi financial distress. Penelitian ini bertujuan untuk mengetahui pengaruh rasio keuangan dan makroekonomi terhadap financial distress perusahaan yang terdaftar di BEI pada industri barang konsumsi tahun 2015-2019.

\section{KAJIAN PUSTAKA DAN PENGEMBANGAN HIPOTESIS}

\section{Du Pont Theory}

Teori $d u$ pont merupakan suatu teori yang menunjukkan informasi mengenai kondisi keuangan perusahaan dengan menggunakan indikator perdagangan, pengelolaan aktiva dan profit margin, sehingga diketahui kondisi kinerja keuangan perusahaan (Sudana, 2011). Analisis dalam teori $d u$ pont dimanfaatkan guna mengevaluasi efektivitas kinerja perusahaan, apabila perusahaan mampu mengoptimalkan rasio aktivitas serta mendapatkan tingkat keuntungan yang besar maka perusahaan juga akan menerima arus kas yang tinggi. Hal tersebut dapat berdampak positif terhadap peningkatan kinerja keuangan karena perusahaan memiliki pendanaan yang cukup (Lianto, 2013).

\section{Trade Off Theory}

Teori ini merupakan teori mengenai struktur modal dimana jika perusahaan dalam pendanaannya lebih mengutamakan dari hutang dibandingkan dengan penghematan pajak, maka besar kemungkinan perusahaan berpotensi mengalami gagal bayar sehingga menyebabkan kebangkrutan perusahaan (Brigham \& Houston, 2014). Asumsi pernyataan tersebut adalah ketika perusahaan tidak melakukan penghematan pajak, melainkan menambah hutangnya maka risiko perusahaan juga akan bertambah besar karena adanya peningkatan bunga yang ditanggung perusahaan seiring dengan meningkatnya hutang yang dimiliki. Dengan adanya hutang perusahaan dapat meningkatkan keuntungan yang diperoleh, namun hal tersebut juga dapat meningkatkan peluang kegagalan bisnis (Brigham \& Houston, 2014).

\section{Teori Keynesian}

Pada tahun 1936 Keynes mencetuskan sebuah teori yang disebut teori keynesian. Teori keynesian merujuk pada konsep kegiatan perekonomian suatu negara tidak hanya dipengaruhi tingkat belanja agregat melainkan juga dipengaruhi oleh kebijakan pemerintah. Kondisi perekonomian yang stabil merupakan tugas dan peran yang dimiliki oleh pemerintah. Untuk menciptakan kondisi tersebut pemerintah membuat instrumen kebijakan yang berupa kebijakan moneter serta pengawasan langsung. Dalam penerapan kebijakan ini, pemerintah menunjuk Bank Indonesia sebagai bank sentral 
Vynda Myllariza. Pengaruh Rasio Keuangan dan Makroekonomi terhadap Financial Distress Perusahaan Sektor Industri Barang Konsumsi yang Terdaftar di BEI Periode 2015-2019

dalam penerapan kebijakan moneter yang berupa alat nilai tukar serta membantu pemerintah agar dapat menstabilkan inflasi (Sukirno, 2005).

\section{Financial Distress}

Financial distress merupakan suatu keadaan yang terjadi pada suatu bisnis yang ditandai dengan kondisi kesulitan finansial. Platt \& Platt (2002) menuturkan financial distress merupakan suatu keadaan yang biasanya dalam bisnis disebabkan posisi keuangan yang tidak sehat sebelum pada akhirnya mengalami kebangkrutan. Perusahaan yang tidak dapat membayarkan kewajibannya ketika jatuh tempo maka perusahaan tersebut sedang menghadapi financial distress. Pengukuran financial distress dalam penelitian ini dilihat dari nilai EPS, Jika laba per saham perusahaan negatif, menyebabkan perusahaan tersebut dapat dikategorikan sedang menghadapi kondisi financial distress. Pada penelitian ini menggunakan variabel dummy, di mana perusahaan dengan EPS negatif dapat dikategorikan sedang menghadapi financial distress dan diberi kode 1. Sedangkan, perusahaan yang memiliki EPS positif dikategorikan tidak menghadapi kondisi financial distress dan diberikan kode 0 (Darmawan, 2017). Menurut Kasmir (2016) untuk mengetahui nilai EPS dapat digunakan rumus pada persamaan (1).

EPS $=\frac{\text { Laba Bersih }}{\text { Jumlah Saham Beredar }}$

\section{Rasio Keuangan}

Rasio keuangan merupakan indikator yang berguna untuk menganalisa finansial perusahaan melalui informasi finansial yang terdapat pada laporan keuangan periodik yang bertujuan untuk menilai kinerja keuangan perusahaan (Harahap, 2011). Rasio keuangan pada perusahaan sangat penting kegunaannya agar perusahaan mengetahui informasi mengenai kondisi keuangan ke depan sehingga dapat dijadikan sebagai model dalam memperkirakan financial distress pada perusahaan (Sayari \& Mugan, 2017). Rasio keuangan pada penelitian ini yaitu rasio profitabilitas, likuiditas serta leverage.

\section{Profitabilitas yang diproksikan dengan ROA}

ROA ialah rasio yang mengukur efektifitas dan efisiensi pengelolaan aset milik perusahaan. ROA memiliki manfaat guna menilai besar laba dari total aset milik perusahaan (Hery, 2016). Tingginya nilai ROA perusahaan mengindikasikan adanya peningkatan laba bersih perusahaan, dan sebaliknya apabila nilai ROA rendah maka perusahaan hanya mampu menghasilkan laba yang rendah. Menurut Kasmir (2016) rumus yang digunakan untuk mengetahui nilai ROA ditunjukkan pada persamaan (2).

$\mathrm{ROA}=\frac{\text { Laba Bersih }}{\text { Total Aset }}$

\section{Profitabilitas yang diproksikan dengan ROE}

ROE ialah rasio guna mengukur kesanggupan perusahaan untuk mengelola modal yang didapatkan dari pemegang saham (shareholders) guna menghasilkan keuntungan (income) bagi perusahaan (Syamsuddin, 2011). Nilai ROE yang tinggi mengindikasikan kemampuan perusahaan dalam pengelolaan modal perusahaan guna mendapatkan laba (income). Menurut Kasmir (2016) rumus yang digunakan untuk mengetahui nilai ROE dapat ditunjukkan pada persamaan (3).

$\mathrm{ROE}=\frac{\text { Laba Setelah Pajak }}{\text { Total Modal }}$

\section{Likuiditas yang diproksikan dengan $\mathrm{CR}$}

CR ialah rasio yang berfungsi guna menilai kesanggupan perusahaan untuk membayar seluruh kewajiban jangka pendeknya (Kasmir, 2016). Nilai rasio CR yang tinggi menunjukkan perusahaan mampu menyelesaikan kewajiban jangka pendek yang dimiliki sebelum habis masa jatuh temponya, maka perusahaan tersebut dapat dikategorikan perusahaan yang likuid (Rohmadini et al., 2018). Kasmir (2016) menyatakan bahwa untuk menilai CR dapat menggunakan persamaan (4).

$$
\mathrm{CR}=\frac{\text { Aset Lancar }}{\text { Hutang Lancar }}
$$




\section{Leverage yang diproksikan dengan DAR}

DAR ialah rasio yang berguna untuk mengetahui perbandingan jumlah hutang dengan jumlah aset. DAR bertujuan guna mengetahui dan menilai kemampuan suatu bisnis untuk melunasi utang yang ditanggungnya melalui aktiva atau kekayaan perusahaan (Wardiyah, 2017). Apabila perusahaan memiliki nilai DAR tinggi berarti aset perusahaan mampu membiayai seluruh kewajibannya, sehingga akan mengurangi probabilitas perusahaan mengalami financial distress. Menurut Kasmir (2016) untuk mengetahui nilai DAR dapat digunakan rumus pada persamaan (5).

DAR $=\frac{\text { Total Hutang }}{\text { Total Aset }}$

\section{Leverage yang diproksikan dengan DER}

DER ialah rasio keuangan guna mengukur kegiatan perusahaan yang dibiayai oleh utang dibanding modalnya sendiri (Kasmir, 2016). Menurut Kriscahyadi (2011) tingginya nilai DER menunjukkan besar komposisi hutang dibanding ekuitas perusahaan yang berarti bahwa dalam membiayai seluruh kegiatannya perusahaan menggunakan hutang yang mana lebih besar dibanding modalnya sendiri. Perusahaan akan berpotensi mengalami financial distress apabila hutang atau kewajiban yang dimilikinya cukup tinggi (Wahyuni et al., 2020). Rumus untuk menghitung DER menurut Subramanyam \& Wild (2010) pada persamaan (6).

DER $=\frac{\text { Total Hutang }}{\text { Total Ekuitas }}$

\section{Makroekonomi}

Makroekonomi merupakan kondisi perekonomian yang terjadi pada suatu negara secara keseluruhan meliputi pertumbuhan ekonomi, stabilitas dan perubahan pada harga, tingkat tenaga kerja serta pengangguran (Mankiw, 2006). Kondisi ini juga tentu akan berdampak bagi industri pada suatu negara yang akan memberikan pengaruh terhadap kebijakan perusahaan (Fahmi, 2014). Menurut Priyatnasari \& Hartono (2019) kebijakan perusahaan dalam mengantisipasi kondisi makroekonomi akan berpengaruh pada pengelolaan kesejahteraan perusahaan.

\section{Inflasi}

Inflasi adalah kondisi yang terjadi pada perekonomian suatu negara yang menyebabkan adanya peningkatan harga barang secara umum. Menurut (Samuelson \& Nordhaus, 2004) pada pengukuran inflasi dapat menggunakan tingkat harga rerata yang disebut indeks harga konsumen (IHK). Tingkat inflasi yang tinggi akan berdampak pada penurunan permintaan masyarakat terhadap suatu barang. Hal tersebut juga akan berdampak pada kegiatan produksi yang menyebabkan penjualan pada perusahaan akan menurun yang diakibatkan oleh berkurangnya permintaan (Darmawan, 2017). Menurut Samuelson \& Nordhaus (2004) tingkat inflasi dapat dihitung dengan menggunakan IHK pada persamaan (7) sebagai berikut.

Laju Inflasi $\mathrm{t}_{\mathrm{t}}=\frac{\mathrm{IHK}_{\mathrm{t}}-\mathrm{IHK}_{\mathrm{t}-1}}{\mathrm{IHK}_{\mathrm{t}-1}} \times 100 \%$

\section{Nilai Tukar}

Nilai tukar adalah harga suatu kurs terhadap mata uang asing yang digunakan untuk alat pertukaran dengan menyesuaikan satuan unit mata uang asing tersebut. Bagi perusahaan nilai tukar sangat berpengaruh untuk kegiatan operasional perusahaan yang mengimpor bahan baku dari negara lain. Melemahnya nilai tukar akan berdampak pada depresiasi rupiah yang menyebabkan kenaikan biaya produksi. Hal tersebut akan meningkatkan probabilitas perusahaan mengalami kondisi financial distress karena adanya penurunan profitabilitas pada perusahaan (Darminto, 2010). Nilai tukar dihitung menurut Darmawan (2017) pada persamaan (8) sebagai berikut.

Nilai Tukar $=\frac{\text { Kurs Jual+Kurs Beli }}{2} \times 100 \%$

\section{Pengaruh Antar Variabel}


Vynda Myllariza. Pengaruh Rasio Keuangan dan Makroekonomi terhadap Financial Distress Perusahaan Sektor Industri Barang Konsumsi yang Terdaftar di BEI Periode 2015-2019

ROA dalam perusahaan bermanfaat untuk menilai kinerja perusahaan dalam mendapatkan laba bersih dengan memanfaatkan aset yang dimilikinya (Sudana, 2011). ROA termasuk dalam bagan teori $d u$ pont yang memiliki manfaat untuk dapat menilai kondisi keuangan suatu perusahaan. Menurut Sudaryanti \& Dinar (2019) perusahaan yang memiliki nilai ROA tinggi menunjukkan bahwa kebutuhan operasional perusahaan mampu tercukupi dengan jumlah pendanaan yang dimilikinya. Karena perusahaan dapat menghasilkan laba yang tinggi, situasi keuangan yang sulit dapat dihindari.Yustika (2015), Nukmaningtyas \& Worokinasih (2018) dan Priyatnasari \& Hartono (2019) mengemukakan ROA berpengaruh signifikan terhadap financial distress.

H1: ROA memengaruhi financial distress perusahaan sektor industri barang konsumsi periode 2015-2019.

ROE dalam perusahaan berfungsi guna menilai besaran laba setelah pajak yang didapatkan perusahaan dengan menggunakan modal yang dimiliki perusahaan tersebut. Menurut Erayanti (2019) ROE yang tinggi berarti perusahaan mampu mengelola modal secara efektif dan efisien dan dapat menghindari masalah keuangan bagi perusahaan, dan sebaliknya, ketika return on equity perusahaan rendah maka probabilitas menghadapi financial distress makin tinggi karena perusahaan tidak sanggup melakukan pengelolaan terhadap modal yang dimiliki secara efisien. Fatmawati \& Rihardjo (2017), dan Maulida et al. (2018) mengemukakan ROE berpengaruh terhadap financial distress.

H2: ROE memengaruhi financial distress perusahaan sektor industri barang konsumsi periode 2015-2019.

CR merupakan indikator keuangan yang dapat dimasukkan ke dalam indikator likuiditas untuk menilai kemampuan perusahaan dalam mengelola utang jangka pendek dengan memanfaatkan aktiva lancar (Shanjaya \& Marlius, 2017). CR merupakan indikator rasio likuiditas dengan perbandingan aset lancar terhadap hutang lancar yang digunakan untuk mengubah aset lancar non kas menjadi kas untuk menjamin kerugian usaha yang timbul. Kondisi financial distress pada suatu perusahaan dapat dihindari apabila jaminan yang dimiliki oleh perusahaan dapat menutup kerugian yang akan terjadi (Erayanti, 2019). Budiarso (2014), Yustika (2015), dan Ginting (2017) menyatakan bahwa CR memengaruhi financial distress.

H3: CR memengaruhi financial distress perusahaan sektor industri barang konsumsi periode 20152019.

DAR adalah indikator yang digunakan untuk menampilkan dan mengukur aset perusahaan yang didanai utang oleh perusahaan (Sudana, 2011). Berdasarkan teori trade off yang mengatakan bahwa perusahaan akan mengalami risiko gagal bayar apabila perusahaan terus menerus menambah hutang dibandingkan dengan menghemat biaya pajak (Brigham \& Houston, 2014). Tingginya nilai DAR pada suatu perusahaan dapat berarti tingginya hutang yang dimiliki, apabila kondisi ini terjadi secara berkelanjutan maka akan meningkatkan risiko gagal bayar dan menyebabkan perusahaan pada kondisi financial distress (Andre \& Taqwa, 2014). Fatmawati \& Rihardjo (2017), Maulida et al. (2018), dan Rohmadini et al. (2018) mengemukakan DAR memengaruhi financial distress.

H4: DAR memengaruhi financial distress perusahaan sektor industri barang konsumsi periode 2015-2019.

DER ialah rasio yang dapat menilai jumlah modal yang dimiliki perusahaan mampu membiayai seluruh hutang atau kewajiban perusahaan tersebut (Kasmir, 2016). Berdasarkan teori trade off yang menjelaskan bahwasannya perusahaan akan mengalami risiko gagal bayar apabila perusahaan terus menerus menambah hutang dibandingkan dengan menghemat biaya pajak (Brigham \& Houston, 2014). Tingginya nilai DER menunjukkan besar komposisi hutang dibanding ekuitas perusahaan yang berarti bahwa dalam membiayai seluruh kegiatannya perusahaan menggunakan hutang lebih besar dibanding modalnya sendiri. Perusahaan akan berpotensi mengalami financial distress apabila hutang 
atau kewajiban yang dimilikinya cukup tinggi (Wahyuni et al., 2020). Maulida et al. (2018) menyatakan DER memengaruhi financial distress.

H5: DER memengaruhi financial distress perusahaan sektor industri barang konsumsi periode 2015-2019.

Inflasi merupakan suatu kondisi yang terjadi pada suatu negara di mana terdapat kenaikan harga barang secara menyeluruh. Peningkatan harga yang terjadi secara tiba-tiba akan menurunkan permintaan dan daya beli konsumen, sehingga akan berdampak pada penurunan profitabilitas perusahaan (Darmawan, 2017). Analisis dengan menggunakan teori keynesian bertujuan guna melihat keterkaitan inflasi terhadap kondisi financial distress. Peningkatan harga barang yang terjadi secara menyeluruh tentu akan berakibat pada menurunnya permintaan konsumen terhadap suatu barang. Hal tersebut juga akan berdampak pada penurunan profitabilitas perusahaan dan jika terjadi secara kontinyu maka akan memicu terjadinya financial distress pada perusahaan. Rohiman dan Damayanti (2017) menemukan bahwa inflasi berpengaruh signifikan terhadap kesulitan keuangan.

H6: Inflasi memengaruhi financial distress perusahaan sektor industri barang konsumsi periode 2015-2019.

Nilai tukar mengandung risiko ketidakpastian yang dapat terjadi pada investor di pasar global ketika melakukan aktivitas investasi. Dalam melakukan investasi, investor harus memperhitungkan premi risiko atas nilai tukar sebagai dampak fluktuasi nilai tukar (Rodoni \& Ali, 2014). Analisis dengan menggunakan teori keynesian bertujuan untuk mengetahui keterkaitan nilai tukar terhadap kondisi financial distress. Widarjo \& Setiawan (2009) mengemukakan bahwa perusahaan akan mengalami penurunan profitabilitas yang diakibatkan dari depresiasi nilai tukar rupiah. Kondisi penurunan rupiah ini akan meningkatkan probabilitas perusahaan mengalami financial distress. Rohiman \& Damayanti (2017) mengemukakan bahwa nilai tukar memengaruhi financial distress

H7: Nilai tukar memengaruhi financial distress perusahaan sektor industri barang konsumsi periode 2015-2019.

\section{METODE PENELITIAN}

Penelitian ini menggunakan metode kuantitatif dengan data penelitian bersifat sekunder. Jenis penelitian merupakan asosiatif kausal. Variabel independen menggunakan rasio keuangan pada perusahaan meliputi ROA, ROE, CR, DAR dan DER, yang berasal dari hasil perhitungan laporan tahunan yang dipublikasikan di website BEI dan website resmi perusahaan serta variabel makroekonomi yang diwakili oleh inflasi dan nilai tukar diperoleh dari situs resmi www.idx.co.id dan www.bps.go.id. Populasi penelitian meliputi seluruh perusahaan yang termasuk dalam sektor industri barang konsumsi yang terdaftar di BEI 2015-2019. Sampel pada penelitian menggunakan teknik purposive sampling dengan berdasarkan kriteria yang meliputi; (1) Perusahaan industri barang konsumsi yang terdaftar di BEI tahun 2015-2019; (2) Perusahaan industri barang konsumsi yang melaporkan keuangannya secara periodik selama tahun 2015-2019. Dari ketentuan ini didapatkan 26 perusahaan sebagai sampel penelitian.

Teknik pengolahan data guna menguji hipotesis dalam penelitian ini yaitu analisis statistik deksriptif dan analisis regresi logistik dengan menggunakan software SPSS 23. Analisis regresi logistik yang digunakan meliputi penggunaan metode 2-log-likelihood untuk menguji seluruh model, metode Negelkerke square untuk menentukan koefisien determinasi, metode Hosmer and Lemeshow untuk menguji kemampuan model, matriks klasifikasi untuk memprediksi ketepatan model, serta langkah terakhir pengujian yaitu estimasi parameter dan interpretasinya.

\section{HASIL DAN PEMBAHASAN}


Vynda Myllariza. Pengaruh Rasio Keuangan dan Makroekonomi terhadap Financial Distress Perusahaan Sektor Industri Barang Konsumsi yang Terdaftar di BEI Periode 2015-2019

\section{Statistik Dekriptif}

Statistik deskriptif memiliki manfaat untuk pengumpulan dan penyajian berbagai data statistik yang dapat memberikan informasi yang jelas dan dapat dipahami. Analisis memberikan gambaran penelitian melalui hubungan antara variabel independen yang dinyatakan dengan ROA, ROE, CR, DAR, DER, inflasi, dan nilai tukar dan variabel dependen. Analisis bertujuan untuk mendeskripsikan ukuran sampel $(\mathrm{N})$, minimum, maksimum, rata-rata, dan standar deviasi dari masing-masing variabel penelitian. (Ghozali, 2016). Pengujian analisis statistik deksriptif ditunjukkan dengan tabel 1 berikut.

Tabel 1.

STATISTIK DEKSRIPTIF

\begin{tabular}{lcrrrr}
\hline & N & Minimum & Maximum & Mean & Std. Deviasi \\
\hline FD & 130 & 0 & 1 &, 16 &, 369 \\
ROA & 130 &,- 150 &, 490 &, 09879 &, 122194 \\
ROE & 130 &,- 230 & 1,350 &, 18628 &, 311189 \\
CR & 130 &, 580 & 9,270 & 2,83477 & 1,950885 \\
DAR & 130 &, 070 & 1,250 &, 38423 &, 190682 \\
DER & 130 & $-5,020$ & 3,560 &, 77808 &, 838884 \\
INFLASI & 130 & 2,720 & 3,610 & 3,16600 &, 302003 \\
NILAI_TUKAR & 130 & 13,436 & 14,481 & 13,83666 &, 370402 \\
Valid N (listwise) & 130 & & & &
\end{tabular}

Sumber: Output SPSS (2021, data diolah)

\section{Uji Keseluruhan Model}

Uji ini merupakan suatu uji yang digunakan untuk mengetahui besar perubahan yang terjadi pada model penelitian jika menyertakan variabel independennya. Uji ini menghitung perbedaan nilai $-2 \log$ Likelihood pada saat sebelum variabel bebas dimasukkan dan setelah dimasukkan. Hasil pengujiannya mengindikasikan sebelum dimasuki variabel independennya nilai -2Log Likelihood sebesar 114,975 dan nilai -2Log Likelihood turun menjadi 11,265 saat setelah dimasuki variabel independen. Penurunan yang dialami oleh -2Log Likelihood sebesar 103,710. Apabila dibandingkan dengan chi square df 7 (130-123) sebesar 14,067 lebih kecil daripada nilai -2Log Likelihood 103,710 sehingga dapat diartikan data yang digunakan cocok dengan model. Hasil pengujian ini mengindikasikan bahwa model dapat diperbaiki dengan menyertakan variabel bebas dalam model.

\section{Koefisien Determinasi}

Koefisien determinasi merupakan suatu uji yang terdapat pada regresi logistik dengan menunjukkan nilai persentase variabel bebas yang memengaruhi variabel terikat. Pengujian ini dilakukan dengan metode Nagelkerke $R$ Square. Hasil uji menunjukkan besarnya nilai Nagelkerke $R$ Square yang diperoleh 0,936 mengindikasikan pada penelitian ini variabel dependen dijelaskan oleh variabel independennya $93,6 \%$, sedangkan selebihnya $6,4 \%$ dipengaruhi variabel lainnya diluar variabel dalam penelitian ini.

\section{Uji Kelayakan Model}

Pengujian ini menggunakan Hosmer and Lemeshow's Goodness of Fit Test yang menyatakan bahwa apabila nilai signifikansinya $>0,05$ atau 5\% maka model dinyatakan layak dikaji tahapan berikutnya. Pengujian ini memperoleh nilai signifikan 1>0,05. Nilai tersebut mengindikasikan model dapat diasumsikan dengan menggunakan nilai pada hasil pengujian. Dengan demikian, data dan model regresi pada penelitian ini telah sesuai, serta uji hipotesis dapat dilakukan.

\section{Ketepatan Klasifikasi}

Matriks klasifikasi dapat digunakan untuk memprediksi ketepatan model yang berfungsi sebagai perhitungan nilai estimasi pada variabel dependennya. Hasil pada pengujian dapat diketahui jumlah dari perusahaan yang diprediksi baik yang menghadapi financial distress ataupun tidak. Pada kolom non FD menunjukkan jumlah prediksi perusahaan yang tidak menghadapi financial distress yaitu 
98,2\% (107/109). Pada pengujian ini didapati bahwa dari jumlah sampel awal 26 perusahaan menunjukkan sebanyak 19 diprediksi mengalami financial distress, sehingga pada kolom mengalami FD dapat ditinjau 2 dari 19 perusahaan yang diuji tersebut didapatkan nilai persentase 90,5\% (19/21) memiliki peluang mengalami financial distress. Secara keseluruhan persentase yang diperoleh sebesar $96,9 \%$.

Tabel 2.

KLASIFIKASI TABEL

\begin{tabular}{lccccc}
\hline \multirow{2}{*}{ Observed } & & & $\begin{array}{c}\text { Predicted } \\
\text { Non FD }\end{array}$ & $\begin{array}{c}\text { FD } \\
\text { FD }\end{array}$ & Percentage Correct \\
\hline \multirow{2}{*}{ Step 1 } & FD & Non FD & 107 & 2 & 98,2 \\
& \multicolumn{2}{c}{ FD } & 2 & 19 & 90,5 \\
& \multicolumn{2}{c}{ Overall Percentage } & & & 96,9 \\
\hline
\end{tabular}

Sumber: Output SPSS (2021, data diolah)

\section{Estimasi Parameter dan Interpretasinya}

Dalam pengujian hipotesis yang dilakukan uji yaitu besar pengaruh dari variabel independen yang terdiri dari ROA, ROE, CR, DAR, DER, inflasi dan nilai tukar pada variabel dependennya yakni financial distress. Pengujian regresi logistik diperoleh hasil yang ditunjukkan dalam tabel 3 yang menyatakan seluruh variabel independen dalam penelitian ini memperoleh nilai signifikan $>0,05$ yang dapat diasumsikan menolak seluruh hipotesis karena tidak ada pengaruh terhadap variabel dependen.

Tabel 3.

\section{HASIL PENGUJIAN HIPOTESIS}

\begin{tabular}{lrr}
\hline & Variabel & Sig. \\
\hline ROA & $-292,012$ &, 193 \\
ROE & 39,554 &, 532 \\
CR & 2,720 &, 301 \\
DAR & 2,456 &, 919 \\
DER & 7,907 &, 246 \\
Inflasi & 3,504 &, 462 \\
Nilai_Tukar & $-1,183$ &, 667 \\
Constant & $-11,815$ &, 771 \\
\hline Sumber: Output SPSS (2021, data diolah) & &
\end{tabular}

\section{Pengaruh ROA terhadap Financial Distress}

Profitabilitas yang diproksikan oleh ROA tidak berpengaruh pada kesulitan keuangan perusahaan sektor industri barang konsumsi. Hasil pengujian menolak hipotesis H1 yang menyatakan ROA memengaruhi financial distress secara signifikan. Menurut Sudaryanti \& Dinar (2019) perusahaan yang memiliki nilai ROA tinggi menunjukkan bahwa kebutuhan operasional perusahaan mampu tercukupi dengan jumlah pendanaan yang dimilikinya. Karena perusahaan dapat menghasilkan laba yang tinggi, maka dapat terhindar dari kesulitan keuangan. Namun pendapat ini ditolak karena hasil pengujian menunjukkan bahwa nilai rata-rata yang diperoleh lebih kecil dari standar deviasi ROA, sehingga menunjukkan bahwa ROA menghasilkan kesenjangan yang jauh antara nilai minimum dan maksimumnya, sehingga mengakibatkan terdapat pengaruh pada hasil pengujian hipotesis. Implikasi teoritis pada penelitian ini yaitu perusahaan tidak perlu berfokus pada nilai ROA yang dihasilkan, karena nilai ROA tidak mampu memprediksi terjadinya kondisi financial distress. Sedangkan implikasi praktisnya adalah bila perusahaan berkehendak untuk meningkatkan rasio profitabilitasnya dapat dilakukan dengan cara melakukan pengelolaan aset secara efektif dan efisien guna meningkatkan perolehan laba. Hasil penelitian ini selaras dengan hasil penelitian dari Marfungatun (2016) dan Rohmadini et al. (2018). 
Vynda Myllariza. Pengaruh Rasio Keuangan dan Makroekonomi terhadap Financial Distress Perusahaan Sektor Industri Barang Konsumsi yang Terdaftar di BEI Periode 2015-2019

\section{Pengaruh ROE terhadap Financial Distress}

Profitabilitas berbasis ROE tidak berpengaruh terhadap kesulitan keuangan perusahaan sektor industri barang konsumsi. Hasil pengujian menyatakan tolak H2 bahwa ROE memengaruhi financial distress secara signifikan. Menurut Erayanti (2019) ROE yang tinggi berarti industri sanggup mengatur aktiva dengan cara optimal, sehingga perusahaan dapat terhindar dari masalah keuangan. Pendapat tersebut ditolak karena tinggi rendahnya nilai ROE pada perusahaan tidak memengaruhi financial distress. Hasil pengujian juga menolak teori $d u$ pont yakni bila bisnis mampu menciptakan profit yang besar, bisnis pula akan memperoleh arus kas yang besar dan dapat meminimalisir terjadinya financial distress. Perbandingan modal yang ada pada nilai ROE perusahaan tidak memiliki kemampuan untuk menghasilkan profitabilitas bagi perusahaan karena pada umumnya perusahaan menggunakan modal sebagai investasi awal sehingga modal tersebut belum dapat dipakai dalam membiayai operasional perusahaan, sehingga antara ROE dan financial distress tidak ada pengaruhnya secara signifikan. Implikasi teoritis pada penelitian ini yaitu perusahaan tidak perlu berfokus pada nilai ROE yang dihasilkan, karena nilai ROE tidak mampu memprediksi terjadinya kondisi financial distress. Implikasi praktisnya adalah bila perusahaan berkehendak untuk meningkatkan rasio profitabilitasnya maka perusahaan dapat mengurangi jumlah investasi pada aktiva guna mengefisiensi penggunaan modal. Hasil penelitian ini selaras dengan hasil penelitian dari Murni (2018), Rohmadini et al. (2018), dan Priyatnasari \& Hartono (2019).

\section{Pengaruh CR terhadap Financial Distress}

Rasio likuiditas yang diproksikan dengan CR tidak memengaruhi financial distress perusahaan. Hasil pengujian menyatakan tolak $\mathrm{H} 3$ bahwa $\mathrm{CR}$ memengaruhi financial distress secara signifikan. Menurut Rohmadini et al. (2018) Nilai rasio CR yang tinggi menunjukkan perusahaan dapat menyelesaikan kewajiban jangka pendek yang dimiliki sebelum habis masa jatuh temponya, maka perusahaan tersebut dapat dikategorikan perusahaan yang likuid. Namun pendapat ini ditolak karena tinggi rendahnya nilai CR pada perusahaan tidak memengaruhi financial distress. Tinginya nilai CR pada perusahaan belum tentu dapat menjamin perusahaan dapat membayarkan utang jangka pendek. Ketika nilai CR perusahaan tinggi, belum tentu menjamin perusahaan tidak akan menghadapi financial distress dan juga sebaliknya jika nilai CR perusahaan rendah belum tentu mengalami kondisi financial distress. Terjadinya keadaan tersebut sebab industri mempunyai pendanaan yang baik, alhasil tidak akan gegabah untuk mencairkan aktiva lancarnya. Pendanaan tersebut dapat digunakan guna melunasi kewajiban jangka pendeknya. Implikasi teoritis pada penelitian ini yaitu perusahaan tidak perlu berfokus pada nilai CR yang dihasilkan, karena nilai CR tidak mampu memprediksi terjadinya kondisi financial distress. Implikasi praktis bagi perusahaan adalah perusahaan dapat mengurangi jumlah hutang lancar guna mengoptimalkan penggunaan pendanaan yang dimiliki. Hasil penelitian ini selaras dengan hasil penelitian dari Marfungatun (2016), Pertiwi (2018), dan Priyatnasari \& Hartono (2019).

\section{Pengaruh DAR terhadap Financial Distress}

Rasio leverage diproksikan dengan DAR tidak memengaruhi financial distress perusahaan. Hasil pengujian menyatakan tolak H4 bahwa DAR memengaruhi financial distress secara signifikan. Menurut Andre \& Taqwa (2014) Tingginya nilai DAR pada suatu perusahaan dapat berarti tingginya hutang yang dimiliki, apabila kondisi ini terjadi secara berkelanjutan maka akan meningkatkan risiko gagal bayar dan menyebabkan perusahaan pada kondisi financial distress. Namun tinggi rendahnya nilai DAR pada perusahaan tidak memengaruhi financial distress. Nilai DAR yang tinggi pada perusahaan tidak mengindikasikan adanya beban atau kewajiban perusahaan yang tinggi maka akan mengurangi laba yang dihasilkan, namun dapat dimungkinkan jika tingginya nilai DAR pada suatu perusahaan tidak disertai dengan tingginya beban atau kewajiban maka perusahaan akar terhindar dari financial distress (Marlin, 2017). Implikasi teoritis pada penelitian ini yaitu perusahaan tidak perlu berfokus pada nilai DAR yang dihasilkan, karena nilai DAR tidak mampu memprediksi terjadinya kondisi financial distress. Implikasi praktis yang dapat dilakukan oleh perusahaan adalah dengan mengendalikan jumlah utang guna mengalokasikan pendanaan yang didapatkan ke pembiayaan yang diperlukan. Hasil penelitian ini selaras dengan hasil penelitian dari Pertiwi (2018). 


\section{Pengaruh DER terhadap Financial Distress}

Rasio leverage diproksikan dengan DER tidak memengaruhi financial distress perusahaan. Hasil pengujian menyatakan tolak H5 bahwa DER memengaruhi financial distress secara signifikan. Menurut Rudianto (2013) tingginya nilai DER suatu perusahaan mengindikasikan tingginya tingkat hutang atau solvabilitas yang akan berdampak pada peningkatan risiko keuangan, namun peluang perusahaan dalam menghasilkan laba juga akan tinggi. Tingkatan pasiva yang besar pasti memengaruhi besaran bobot bunga yang hendak dijamin oleh perusahaan, sehingga risiko yang diterima oleh investor juga semakin besar. Namun apabila hutang dapat digunakan untuk meningkatkan modal yang dimiliki akan dapat membantu perusahaan dalam kegiatan operasional dan perusahaan mampu mengelolanya dengan baik akan diperoleh profit yang besar juga bagi perusahaan (Wahyuni et al., 2020). Implikasi teoritis pada penelitian ini yaitu perusahaan tidak perlu berfokus pada nilai DER yang dihasilkan, karena nilai DER tidak mampu memprediksi terjadinya kondisi financial distress. Sedangkan implikasi praktisnya adalah perusahaan dapat memilih sumber pendanaan dengan risiko rendah dan berusaha untuk mengoptimalkan pengelolaan perusahaan agar dapat meningkatkan keuntungan perusahaan. Hasil penelitian ini selaras dengan hasil penelitian dari Sucipto \& Muazaroh (2017), Setiawan et al. (2017), dan Murni (2018).

\section{Pengaruh Inflasi terhadap Financial Distress}

Makroekonomi diproksikan dengan inflasi tidak memengaruhi financial distress perusahaan. Hasil pengujian menyatakan tolak H6 bahwa inflasi memengaruhi financial distress secara signifikan. Menurut Darmawan (2017) kondisi inflasi pada suatu negara dapat menurunkan permintaan konsumen, sehingga akan menurunkan profitabilitas bagi perusahaan dan dapat menyebabkan terjadinya financial distress. Namun tinggi rendahnya inflasi tidak memengaruhi financial distress karena inflasi dalam penelitian ini terjadi pada tahun 2015-2019 memiliki nilai rata-rata yang cukup rendah, sehingga dapat dikatakan bahwa tingkat inflasi yang terjadi masih berada pada kondisi yang stabil. Tingkat inflasi yang masih berada kondisi stabil memungkinkan perusahaan untuk dapat mengontrol dan mengantisipasi kondisi keuangan perusahaan sehingga perusahaan dapat meminimalisir kondisi financial distress pada perusahaan. Implikasi teoritis pada penelitian ini yaitu perusahaan tidak perlu berfokus pada tingkat inflasi, karena inflasi tidak dapat digunakan untuk memprediksi terjadinya kondisi financial distress. Sedangkan implikasi praktisnya adalah pada saat menghadapi kondisi inflasi yang sedang terjadi perusahaan dapat mengambil langkah dengan cara melakukan efisiensi biaya internal serta melakukan inovasi dan variasi pada produk sebagai bentuk antisipasi dan kontrol oleh perusahaan. Hasil penelitian ini selaras dengan hasil penelitian dari Darmawan (2017), dan Priyatnasari \& Hartono (2019).

\section{Pengaruh Nilai Tukar terhadap Financial Distress}

Makroekonomi yang diproksikan dengan nilai tukar tidak memengaruhi financial distress perusahaan. Hasil pengujian menyatakan tolak $\mathrm{H} 7$ bahwa nilai tukar memengaruhi financial distress secara signifikan. Widarjo \& Setiawan (2009) mengemukakan bahwa perusahaan akan mengalami penurunan profitabilitas yang diakibatkan dari depresiasi nilai tukar rupiah. Kondisi penurunan rupiah ini akan meningkatkan probabilitas perusahaan mengalami financial distress. Namun tinggi rendahnya nilai tukar tidak memengaruhi financial distress. Hal tersebut disebabkan oleh penggunaan sistem hedging yang dilakukan oleh Bank Indonesia sehingga keuangan perusahaan tidak terpengaruh dengan fluktuasi nilai tukar (Darmawan, 2017). Fluktuasi nilai tukar terhadap rupiah yang terjadi pada periode 2015-2019 tidak terlalu tinggi sehingga menyebabkan tidak adanya pengaruh antara nilai tukar dengan kondisi financial distress pada perusahaan. Implikasi teoritis pada penelitian ini yaitu perusahaan tidak perlu berfokus pada nilai tukar, karena nilai tukar tidak mampu memprediksi terjadinya kondisi financial distress. Sedangkan implikasi praktis bagi perusahaan adalah dalam membantu pemerintah untuk memperkuat nilai tukar rupiah, perusahaan dapat mengurangi kegiatan impor bahan produksi dengan menggunakan bahan pengganti atau substitusi lokal. Hasil penelitian ini selaras dengan hasil penelitian dari Darmawan (2017). 
Vynda Myllariza. Pengaruh Rasio Keuangan dan Makroekonomi terhadap Financial Distress Perusahaan Sektor Industri Barang Konsumsi yang Terdaftar di BEI Periode 2015-2019

\section{KESIMPULAN}

Berlandaskan hasil pengujian dan analisa data di atas maka dapat dikatakan bahwa rasio keuangan yang meliputi rasio profitabilitas (ROA dan ROE), likuiditas (CR), dan leverage (DAR dan DER) tidak memengaruhi financial distress. Hasil pengujian hipotesis mengemukakan bahwa rasio keuangan tersebut tidak memengaruhi kondisi financial distress pada perusahaan sektor industri barang konsumsi. Tinggi rendahnya suatu rasio keuangan tidak selalu terdapat pengaruh terhadap financial distress, kemampuan perusahaan dalam mengelola dan memanfaatkan pendanaan yang dimilikinya dapat menghasilkan profitabilitas yang tinggi sehingga dapat membantu perusahaan terhindar dari kondisi financial distress yang dapat menyebabkan kebangkrutan. Selain itu, variabel makroekonomi (inflasi dan nilai tukar) yang diuji pada penelitian ini juga tidak memengaruhi financial distress disebabkan karena adanya sistem hedging yang dilakukan oleh Bank Indonesia dan juga adanya antisipasi dan kontrol yang baik dari perusahaan sehingga perusahaan akan terhindar dari financial distress yang ditimbulkan dari faktor makroekonomi.

Penelitian ini masih mempunyai beberapa keterbatasan yang dapat memengaruhi hasil penelitian. Keterbatasan tersebut antara lain objek dan periode pengamatan. Penelitian berikutnya disarankan agar dapat memperluas objek dan periode penelitian sehingga data menjadi lebih representatif. Selain itu juga dapat menggunakan proksi selain EPS untuk memprediksi financial distress, serta diharapkan untuk dapat menambah rasio keuangan lainnya selain rasio profitabilitas, likuiditas, dan leverage seperti rasio aktivitas, dan rasio arus kas. Indikator makroekonomi juga dapat diperluas dengan menambah indikator lainnya seperti suku bunga dan GDP.

\section{DAFTAR PUSTAKA}

Aisyah, N. N., Kristanti, F. T., \& Zultilisna, D. (2017). Pengaruh Rasio Likuiditas, Rasio Aktivitas, Rasio Profitabiltas, dan Rasio Leverage terhadap Financial Distress (Studi pada Perusahaan Tekstil dan Garmen yang Terdaftar di Bursa Efek Indonesia Tahun 2011-2015). E-Proceeding of Management, 4(1), 411-419.

Andre, O., \& Taqwa, S. (2014). Pengaruh Profitabilitas, Likuiditas, dan Leverage dalam Memprediksi Financial Distress (Studi Empiris pada Perusahaan Aneka Industri yang Terdaftar di BEI Tahun 2006-2010). Jurnal WRA, 2(1), 293-312.

Brigham, E. F., \& Houston, J. F. (2014). Dasar-Dasar Manajemen Keuangan (11th ed.). Jakarta: Salemba Empat.

Budiarso, N. S. (2014). Pengaruh Struktur Kepemilikan, Likuiditas dan Leverage terhadap Financial Distress. Jurnal Accountability, 3(2).

Darmawan, S. (2017). Analisis Pengaruh Corporate Governance, Variabel Ekonomi Makro terhadap Financial Distress dengan Variabel Kontrol Ukuran Perusahaan dan Jenis Kepemilikan. Jurnal Ekonomi dan Bisnis, 7(1), 100-122.

Darminto. (2010). Pengaruh Faktor Eksternal dan Berbagai Keputusan Keuangan terhadap Nilai Perusahaan. Jurnal Aplikasi Manajemen, 8(1).

Erayanti, R. (2019). Pengaruh Likuiditas, Profitabilitas dan Leverage terhadap Prediksi Financial Distress. Jurnal Riset Akuntansi dan Perpajakan, 6(1), 38-50.

Fahmi, I. (2014). Analisis Kinerja Keuangan. Bandung: Alfabeta.

Fatmawati, V., \& Rihardjo, I. B. (2017). Pengaruh Likuiditas, Leverage, Aktivitas dan Profitabilitas dalam Memprediksi Financial Distress. Jurnal Ilmu dan Riset Akuntansi, 6(10). 
Ghozali, I. (2016). Aplikasi Analisis Multivariate dengan Program IBM SPSS 23. Semarang: Badan Penerbit Universitas Diponegoro.

Ginting, M. C. (2017). Pengaruh Current Ratio dan Debt to Equity Ratio (DER) terhadap Financial Distress pada Perusahaan Property \& Real Estate di Bursa Efek Indonesia. Jurnal Manajemen, $3(2), 37-44$.

Harahap, S. S. (2011). Analisis Kritis atas Laporan Keuangan. Jakarta: Raja Grafindo Persada.

Hery. (2016). Analisis Laporan Keuangan Integrated and Comprehensive Edition. Jakarta: PT Gramedia.

Kasmir. (2016). Analisis Laporan Keuangan (1st ed.). Jakarta: Rajawali Press.

Kriscahyadi, H. T. (2011). Analisis Pengaruh Free Cash Flow, Cash Position, Debt to Equity Ratio dan Company Size terhadap Devidend Payout Ratio pada Perusahaan Manufaktur di BEI Tahun 2008-2010. Jurnal Akuntansi, 4(5), 81-96.

Lianto, D. (2013). Penilaian Kinerja Keuangan Perusahaan Menggunakan Analisis Du Pont. Jurnal JIBEKA, 7(2), 25-31.

Mankiw, N. G. (2006). Pengantar Teori Ekonomi Makro (Edisi 3). Jakarta: Salemba Empat.

Marfungatun, F. (2016). Pengaruh Rasio Profitabilitas, Likuiditas dan Leverage terhadap Kondisi Financial Distress (Studi Empiris pada Perusahaan Manufaktur yang Terdaftar di Bursa Efek Indonesia Periode 2013-2015). Jurnal Ekonomi dan Bisnis, 1(1).

Marlin, Y. (2017). Pengaruh Current Ratio, Debt to Asset Ratio dan Total Asset Turnover terhadap Kondisi Financial Distress. E-Jurnal Administrasi Bisnis, 5(4), 855-866.

Maulida, I. S., Moehaditoyo, S. H., \& Nugroho, M. (2018). Analisis Rasio Keuangan untuk Memprediksi Financial Distress pada Perusahaan Manufaktur yang Terdaftar di Bursa Efek Indonesia 2014-2016. JIABI, 2(1), 179-193.

Murni, M. (2018). Analisis Faktor-Faktor yang Mempengaruhi Tingkat Financial Distress pada Perusahaan Manufaktur yang Terdaftar di BEI Tahun 2010-2014. Jurnal Akuntansi dan Bisnis, 4(1), 74-83.

Nukmaningtyas, F., \& Worokinasih, S. (2018). Kas untuk Memprediksi Financial Distress (Studi pada Perusahaan Sektor Aneka Industri yang Terdaftar di Bursa Efek Indonesia Periode 2013 2016). Jurnal Administrasi Bisnis (JAB), 61(2), 136-143.

Pertiwi, D. A. (2018). Pengaruh Rasio Keuangan, Growth, Ukuran Perusahaan dan Inflasi terhadap Financial Distress di Sektor Pertambangan yang Terdaftar di Bursa Efek Indonesia (BEI) Periode 2012 - 2016. Jurnal Ilmu Manajemen, 6(3), 359-366.

Platt, H. D., \& Platt, M. B. (2002). Predicting Corporate Financial Distress: Reflections on Choice Based Sample Bias. Journal of Economics and Finance, 26(2), 184-199. https://doi.org/10.1007/bf02755985

Priyatnasari, S., \& Hartono, U. (2019). Rasio Keuangan, Makroekonomi dan Financial Distress: Studi pada Perusahaan Perdagangan, Jasa dan Investasi di Indonesia. Jurnal Ilmu Manajemen, 7(4), $1005-1016$.

Rodoni, A., \& Ali, H. (2014). Manajemen Keuangan Modern. Jakarta: Mitra Wacana Media. 
Vynda Myllariza. Pengaruh Rasio Keuangan dan Makroekonomi terhadap Financial Distress Perusahaan Sektor Industri Barang Konsumsi yang Terdaftar di BEI Periode 2015-2019

Rohiman, S. F., \& Damayanti, C. R. (2017). Pengaruh Inflasi, Nilai Tukar dan Suku Bunga terhadap Financial Distress (Studi pada Semua Perusahaan yang Terdaftar di Bursa Efek Indonesia Periode 2013- 2017). Jurnal Administrasi Bisnis, 72(2), 186-195.

Rohmadini, A., Saifi, M., \& Darmawan, A. (2018). Pengaruh Profitabilitas, Likuiditas dan Leverage terhadap Financial Distress (Studi pada Perusahaan Food \& Beverage yang Terdaftar di Bursa Efek Indonesia Periode 2013-2016). Jurnal Administrasi Bisnis (JAB), 61(2), 11-19.

Rudianto. (2013). Akuntansi Manajemen. Jakarta: Erlangga.

Samuelson, P. A., \& Nordhaus, W. D. (2004). Ilmu Makroekonomi (17th ed.). Jakarta: PT. Media Global Edukasi.

Sari, A. N., \& Hartono, U. (2020). Faktor-Faktor Internal yang Memengaruhi Financial Distress pada Perusahaan Sektor Industri Barang Konsumsi yang Terdaftar di BEI Tahun 2015-2019. Jurnal Ilmu Manajemen, 8(4).

Sayari, N., \& Mugan, C. S. (2017). Industry Specific Financial Distress Modeling. BRQ Business Research Quarterly, 20(1), 45-62. https://doi.org/10.1016/j.brq.2016.03.003

Setiawan, D., Oemar, A., \& Pranaditya, A. (2017). Pengaruh Laba, Arus Kas, Likuiditas Perusahaan, Ukuran Perusahaan, Leverage, Kepemilikan Institusional dan kepemilikan Manajerial untuk Memprediksi Kondisi Financial Distress (pada Perusahaan Manufaktur yang Terdapat di BEI Periode Tahun 2010-2015). Jurnal Ekonomi Dan Bisnis, 3(3), 1-15.

Shanjaya, A. R., \& Marlius, D. (2017). Peranan Laporan Keuangan dalam Kebijaksanaan Pemberian Kredit kepada Calon Nasabah Pada PT. BPR Batang Kapas. Jurnal Akuntansi Keuangan, 12(1).

Simanjuntak, C., Dr. Farida Titik K, S.E., M. S., \& Wiwin Aminah, S.E., M.M., A. (2017). Pengaruh Rasio Keuangan terhadap Financial Distress (Studi pada Perusahaan Transportasi yang Terdaftar di Bursa Efek Indonesia 2011-2015). E-Proceeding of Management, 4(2), 1-8.

Subramanyam, K. R., \& Wild, J. J. (2010). Analisis Laporan Keuangan (10th ed.). Jakarta: Salemba Empat.

Sucipto, A. W., \& Muazaroh. (2017). Kinerja Rasio Keuangan untuk Memprediksi Kondisi Financial Distress pada Perusahaan Jasa di Bursa Efek Indonesia Periode 2009-2014. Journal of Business and Banking, 6(1), 81-98. https://doi.org/10.14414/jbb.v6i1.

Sudana, I. M. (2011). Manajemen Keuangan Perusahaan (E. Novietha I. Sallama (ed.)). Jakarta: Erlangga.

Sudaryanti, D., \& Dinar, A. (2019). Analisis Prediksi Kondisi Kesulitan Keuangan dengan Menggunakan Rasio Likuiditas, Profitabilitas, Financial Leverage dan Arus Kas. Jurnal Ilmiah Bisnis dan Ekonomi Asia, 13(2), 101-110. https://doi.org/10.32812/jibeka.v13i2.120

Sukirno, S. (2005). Perkembangan Pemikiran dari Klasik Hingga Keynesian Baru. Jakarta: PT Raja Grafindo Persada.

Syamsuddin, L. (2011). Manajemen Keuangan Perusahaan (Konsep Aplikasi dalam: Perencanaan, Pengawasan, dan Pengambilan Keputusan) (Edisi Baru). Jakarta: PT Raja Grafindo Persada.

Tandelilin, E. (2010). Pengantar Pengetahuan Pasar Modal (6th ed.). Yogyakarta: UPP Sekolah Tinggi Ilmu Manajemen YKPN. 
Thim, C. K., Chong, Y. V., \& Chai, S. N. (2011). Factors Affecting Financial Distress: The Case of Malaysian Public Listed Firms. The Case of Malaysian Public Listed Firms, 8(4), 345-351.

Wahyuni, S. F., Farisi, S., \& Jufrizen. (2020). Faktor Determinan Financial Distress pada Perusahaan Sektor Manufaktur yang Terdaftar di Bursa Efek Indonesia. Journal of Economics and Business Mulawarman, 16(2), 286-298.

Wardiyah, M. L. (2017). Analisis Laporan Keuangan (Edisi 1). Bandung: CV Pustaka Setia.

Widarjo, W., \& Setiawan, D. (2009). Pengaruh Rasio Keuangan terhadap Kondisi Financial Distress Perusahaan Otomotif. Jurnal Bisnis dan Akuntansi, 11(2), 107-119.

Widhiari, N., \& Aryani Merkusiwati, N. (2015). Pengaruh Rasio Likuiditas, Leverage, Operating Capacity, dan Sales Growth terhadap Financial Distress. E-Jurnal Akuntansi, 11(2), 456-469.

Yustika, Y. (2015). Pengaruh Likuiditas, Leverage, Profitabilitas, Operating Capacity dan Biaya Agensi Manajerial terhadap Financial Distress (Studi Empiris pada Perusahaan Manufaktur yang Terdaftar di Bursa Efek Indonesia Tahun 2011-2013). Jurnal Online Mahasiswa Fakultas Ekonomi, 2(2), 1-15. 